\title{
BEHAVIORAL INTENTION PENUMPANG KRL COMMUTER LINE JABODETABEK
}

\author{
Ronald Sukwadi *), Grandee Teofilus \\ Program Studi Teknik Industri, Fakultas Teknik, Universitas Katolik Indonesia Atma Jaya \\ Jl. Jenderal Sudirman 51, Jakarta, Indonesia 12930
}

\begin{abstract}
Abstrak
Behavioral intention dipandang sebagai penentu utama kinerja penyedia transportasi umum. Penelitian ini menekankan pada hubungan antara behavioral intention dan variabel-variabel yang mempengaruhinya seperti kualitas layanan, nilai yang dirasakan, keterlibatan, dan kepuasan penumpang. Dengan melakukan survei penumpang Kereta Rel Listrik (KRL) Commuter Line Jabodetabek, teknik model persamaan struktural menggunakan software AMOS 22.0 digunakan untuk menganalisis hubungan antar variabel dalam model konseptual. Hasil penelitian mengungkapkan bahwa kualitas layanan memiliki dampak positif terhadap nilai yang dirasakan. Nilai yang dirasakan dan kepuasan penumpang mempunyai dampak positif terhadap keterlibatan. Kualitas layanan dan keterlibatan memiliki dampak positif terhadap behavioral intention.
\end{abstract}

Kata kunci: behavioral intention; kualitas layanan; nilai yang dirasakan; keterlibatan; kepuasan

\begin{abstract}
The behavioral intention of public transportation passengers is seen as a crucial determinant of public transportation provider performance. This research highlights the relationships between passenger behavioral intention and the various variables that affect it such as service quality, perceived value, involvement, and satisfaction of public transportation services. By using passenger survey data from the Kereta Rel Listrik (KRL) Commuter Line Jabodetabek, the structural equation modeling technique AMOS 22.0 is applied to analyze the conceptualized relationship model. The findings reveal that service quality has positive effect to perceived value. Perceived value and customer satisfaction have positive effect to involvement. Service quality and involvement have positive effect to behavioral intention.
\end{abstract}

Keywords: behavioral intention; service quality, perceived value; involvement; satisfaction

\section{Pendahuluan}

Transportasi merupakan sarana perkembangan yang penting dan strategis dalam memperlancar roda perekonomian serta mempengaruhi semua aspek kehidupan masyarakat (Jen \& Hu, 2003; Joewono \& Kubota, 2007; Lai \& Lu, 2007). Transportasi juga merupakan sarana penting dalam memfasilitasi hubungan antar wilayah/daerah melalui proses interaksi dan komunikasi yang terjadi. Untuk melayani mobilitas penduduk Jakarta, pemerintah menyediakan sarana bus PPD, metromini, mikrolet, dan Trans Jakarta. Selain itu, terdapat pula ojek, bajaj, dan bemo untuk jarak pendek. Selain itu, sarana transportasi darat andalan masyarakat Jakarta dan sekitarnya adalah kereta rel listrik atau yang biasa dikenal dengan KRL Commuter Line Jabodetabek.

\footnotetext{
${ }^{*}$ Penulis Korespondensi. E-mail: ronald.sukwadi@atmajaya.ac.id
}

Jurnal Teknik Industri, Vol. X, No. 2, Mei 2015
Kereta listrik ini beroperasi dari pagi hari hingga malam hari. Data terbaru didapat bahwa sepanjang kuartal pertama pada tahun 2014 dari (Januari hingga Maret 2014), BPS (Badan Pusat Statistik) menyatakan bahwa jumlah penumpang KRL Commuter Line Jabodetabek bulan Januari 2014 sebesar 14.963 orang, bulan Februari 2014 sebesar 14.303 orang, dan pada bulan Maret 2014 sebesar 16.909 orang.

Parasuraman dkk. $(1985,1988)$ juga menyatakan ada lima dimensi yang digunakan oleh pelanggan untuk menilai kualitas pelayanan pada suatu industri jasa yaitu: (1) Keandalan (reliability) merupakan suatu kemampuan untuk memberikan jasa yang dijanjikan dengan akurat dan terpercaya, dimana kinerja harus sesuai dengan harapan pelanggan yaitu ketepatan waktu, pelayanan yang sama untuk semua pelanggan tanpa ada kesalahan; (2) Ketanggapan (responsiveness), yaitu dengan memberikan pelayanan yang cepat kepada pelanggan; (3) Jaminan (assurance), yaitu pengetahuan dan keramahan karyawan serta kemampuan melaksanakan tugas yang dapat menjamin kinerja yang baik sehingga 
menimbulkan kepercayaan dan keyakinan pelanggan; (4) Empati (emphaty), yaitu memberikan perhatian yang bersifat individual atau pribadi kepada pelanggan dan berupaya untuk memahami keinginan konsumen; (5) Berwujud (tangibles), yaitu penampilan dan kemampuan sarana dan prasarana fisik yang dapat diandalkan, serta keadaan lingkungan sekitar sebagai bukti nyata dari pelayanan yang disediakan.

Nilai yang dirasakan (perceived value) didefinisikan sebagai penilaian konsumen secara keseluruhan kegunaan produk [atau jasa] berdasarkan persepsi apa yang diterima dan apa yang diberikan (Zeithaml, 1988). Dengan kata lain, nilai yang dirasakan merupakan perbandingan antara manfaat yang dirasakan dan biaya yang dikeluarkan (Cronin dkk., 2000; Jen \& Hu, 2003; Lam dkk., 2004). Nilai yang dirasakan cenderung tinggi jika manfaat yang dirasakan lebih tinggi dari yang biaya dirasakan dan sebaliknya (Chen, 2008; Chen \& Tsai, 2008).

Keterlibatan (involvement) mengacu kepada persepsi pelanggan mengenai tingkat kepentingan dan relevansi suatu kegiatan (Peter \& Olson, 2008; Schiffman dkk., 2010). Blackwell dkk. (2001), Mowen (1993), dan Solomon (2011), memberikan definisi yang sama dengan tambahan tingkat kepentingan tersebut dihasilkan dari suatu rangsangan dalam situasi tertentu. Menurut Beatty dkk. (1998) dan Bennett dkk. (2005) paling tidak ada lima komponen keterlibatan, yaitu: (1) kepentingan produk buat pelanggan (product importance); (2) minat konsumen terhadap produk (interest); (3) resiko pembelian dan mengkonsumsi produk (risk); (4) sejauh mana produk merepresentasikan diri pelanggan (badge value); (5) sejauh mana pelanggan memiliki ikatan emosional terhadap produk tersebut (emotion).

Kepuasan terhadap jasa transportasi KRL merupakan keseluruhan konstruksi yang dipengaruhi oleh ekspektasi penumpang dan persepsi kinerja pada periode tertentu, dan juga dipengaruhi oleh kepuasan masa lalu dari periode ke periode (Cronin dkk., 2000). Dari definisi ini, kepuasan pelanggan terletak pada diskonfirmasi paradigma harapan pelanggan, sedangkan diskonfirmasi positif menyebabkan kepuasan pelanggan dan negatif kepuasan menyebabkan ketidakpuasan pelanggan (Lam dkk., 2004; Petrick, 2004). Kepuasan pelanggan ditentukan oleh persepsi pelanggan atas kinerja produk atau jasa dalam memenuhi harapan. Pelanggan merasa puas apabila harapanya terpenuhi atau akan sangat puas jika harapan pelanggan terlampaui, ada lima faktor utama pelanggan yaitu kualitas produk, harga, kualitas layanan, faktor emosional, biaya, dan kemudahan (Irawan, 2008).

Behavioral intention sebagai tindakan untuk mewakili loyalitas pelanggan (Petrick, 2004). Oleh karena itu, behavioral intention mencakup pembelian kembali dan niat rekomendasi (Zeithaml dkk., 1996; Chen, 2008). Pengukuran niat berperilaku (behavioral intention) dapat menjadi cara terbaik untuk memprediksikan perilaku pembelian yang akan datang
(Petrick, 2004; Sumaedi dkk., 2012). Pendapat ini ditegaskan oleh Zeithaml dkk. (1996) yang mengatakan konsekuensi yang timbul dari persepsi terhadap kualitas jasa dalam bentuk niat berperilaku konsumen individual dapat dipandang sebagai sinyal keberhasilan atau kegagalan perusahaan untuk mempertahankan pelanggannya.

Dalam penelitian ini, peneliti ingin mengetahui niat perilaku (behavioral intention) masyarakat Jakarta dan sekitarnya terhadap jasa transportasi KRL Jabodetabek. Dalam hal ini, peneliti ingin mengetahui peran kualitas layanan, nilai yang dirasakan, keterlibatan, dan kepuasan penumpang terhadap behavioral intention. Model penelitian dengan SEM (Structural Equation Modeling) untuk menganalisis hubungan antara variabel-variabel tersebut.

\section{Metode Penelitian \\ Desain Penelitian}

Objek penelitian adalah kereta rel listrik (KRL) Jabodetabek. Data diperoleh melalui penyebaran kuisioner pada penumpang KRL tersebut dengan teknik purposive sampling. Kuesioner terbagi menjadi dua bagian besar. Bagian pertama berisi pernyataan mengenai data demografi responden. Bagian kedua berisi 15 indikator yang terdiri dari 56 pernyataan yang diturunkan penelitian-penelitian terdahulu yang menggambarkan persepsi penumpang (Tabel 1). Pada bagian ini, responden diminta memilih satu dari lima pilihan jawaban yang dituliskan dalam skala pengukuran Likert 1 sampai 5, masingmasing menunjukkan sangat tidak setuju (1), tidak setuju (2), netral (3), setuju (4), sangat setuju (5) terhadap setiap pernyataan dalam kuesioner. Sebanyak 250 kuesioner disebarkan secara langsung pada beberapa stasiun maupun secara online. Dari 250 kuesioner, diperoleh hanya 200 data yang dapat digunakan untuk analisis lebih lanjut. Jumlah sampel ini sudah memenuhi jumlah sampel yang direkomendasikan untuk model persamaan struktural yaitu sebesar 150-400 responden (Hair dkk., 2010).

Tabel 1. Variabel dan indikator penelitian

\begin{tabular}{ll}
\hline \multicolumn{1}{c}{ Varibel } & \multicolumn{1}{c}{ Indikator } \\
\hline Kualitas layanan & Keamanan \\
& Kenyamanan \\
& Sikap Karyawan \\
& Kondisi \\
Nilai yang dirasakan & Fitur \\
& Keandalan \\
& Informasi \\
& Biaya \\
Kepuasan & Loyalitas \\
& Reaksi positif \\
Keterlibatan & Orientasi \\
& Keterlibatan Penumpang \\
Behavioral intention & Tingkat kepercayaan \\
& Rekomendasi \\
& Pilihan \\
\hline
\end{tabular}


Pengembangan Hipotesis dan Model Penelitian

Dalam penelitian-penelitian terdahulu, kualitas layanan dianggap sebagai penentu behavioral intention (Cronin dkk., 2000; Hu \& Jen, 2006). Kualitas layanan dapat mempengaruhi behavioral intention secara langsung (Petrick, 2004; Chen, 2008; Sumaedi dkk., 2012) atau mempengaruhi behavioral intention secara tidak langsung melalui kepuasan (Cronin \& Taylor, 1992) dan nilai yang dirasakan (Zeithaml, 1988). Dalam konteks transportasi publik, hubungan positif langsung antara kualitas layanan dan behavioral intention telah dikonfirmasi oleh penelitian Chen (2008). Selain itu, peneliti lain menemukan layanan yang pengaruh kualitas layanan terhadap behavioral intention secara langsung melalui kepuasan (Joewono \& Kubota, 2007) dan nilai yang dirasakan (Jen \& Hu, 2003). Oleh karena itu, hipotesis yang dapat dibangun adalah sebagai berikut:

$H 1$ : Kualitas layanan mempunyai efek yang positif terhadap nilai yang dirasakan.

H2 : Kualitas layanan mempunyai efek yang positif terhadap kepuasan penumpang.

H5 : Nilai yang dirasakan mempunyai efek yang positif terhadap kepuasan penumpang

$H 7$ : Nilai yang dirasakan mempunyai efek yang positif terhadap behavioral intention.

H9 : Kepuasan penumpang mempunyai efek yang positif terhadap behavioral intention.

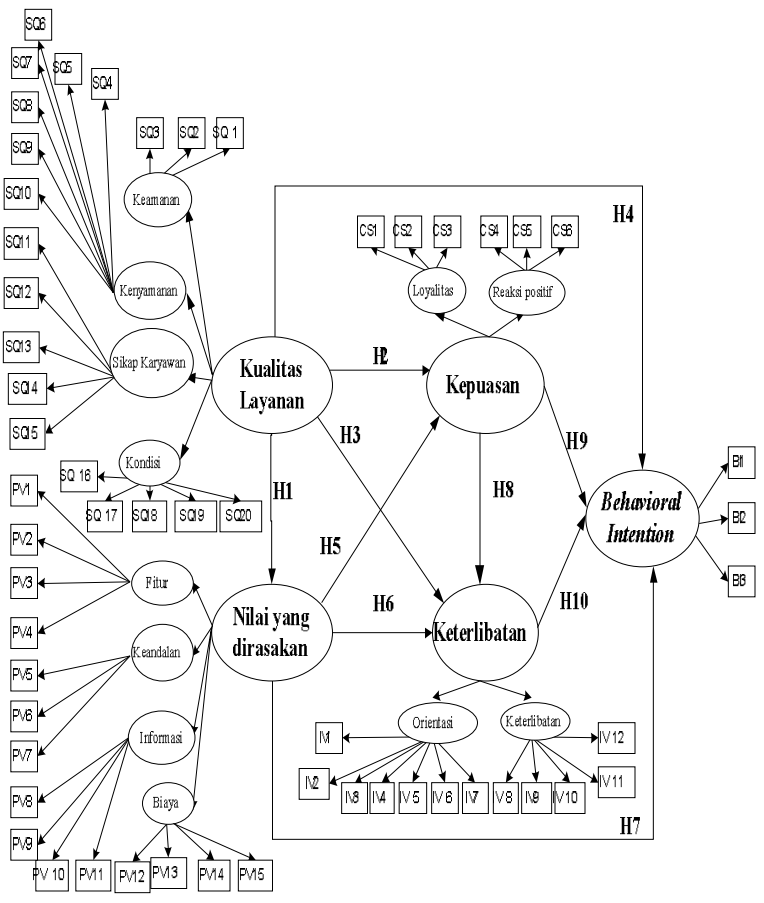

Gambar 1. Model awal penelitian

Keterlibatan penumpang (involvement) juga banyak digunakan sebagai variabel konstruk dalam banyak studi hubungan sikap-perilaku dan dalam aspek lain dari riset pemasaran (Peter \& Olson, 2008;

Jurnal Teknik Industri, Vol. X, No. 2, Mei 2015
Schiffman dkk., 2010; Solomon, 2011). Beberapa penelitian juga meneliti efek moderasi variabel keterlibatan pada hubungan kepuasan-loyalitas (Beatty dkk.,1988; Zaichkowsky, 1994). Faktanya, keterlibatan dapat berubah karena perubahan sikap pelanggan terhadap persepsi kualitas layanan, seperti nilai yang dirasakan, kualitas layanan, dan kepuasan. Dalam studi tersebut, faktor keterlibatan dimodifikasi setelah pengalaman layanan pelanggan digunakan sebagai variabel moderator dan hasilnya antara keterlibatan berpengaruh positif terhadap behavioral intention (Sumaedi dkk., 2011). Penelitian ini juga menyatakan bahwa beberapa faktor lain seperti kepuasan maupun nilai yang dirasakan juga berpengaruh positif terhadap behavioral intention. Berikut ini merupakan hipotesis yang dapat dibangun:

H3 : Kualitas layanan mempunyai efek yang positif terhadap keterlibatan.

H4 : Kualitas layanan mempunyai efek yang positif terhadap behavioral intention.

H6 : Nilai yang dirasakan mempunyai efek yang positif terhadap keterlibatan.

H8 : Kepuasan penumpang mempunyai efek yang positif terhadap keterlibatan.

H1O : Keterlibatan mempunyai efek yang positif terhadap behavioral intention.

\section{Hasil dan Pembahasan \\ Profil Responden}

Profil responden penumpang KRL Jabodetabek dapat dilihat pada Tabel 2.

Tabel 2. Profil demografi responden $(N=200)$

\begin{tabular}{lc}
\hline \multicolumn{1}{c}{ Karakteristik } & Jumlah \\
\hline Jenis Kelamin & \\
Pria & 108 \\
Wanita & 92 \\
Pendidikan Terakhir & \\
SMA ke bawah & 111 \\
Diploma ke atas & 89 \\
Profesi & \\
Pelajar/Mahasiswa & 63 \\
Karyawan & 93 \\
Lain-lain & 23 \\
Pengeluaran/bulan & \\
$\quad$ < 3 juta rupiah & 125 \\
3 juta-5 juta rupiah & 56 \\
> 5 juta rupiah & 19 \\
Frekuensi & \\
Setiap hari & 93 \\
3-4 x seminggu & 70 \\
Kadang-kadang & 37 \\
\hline
\end{tabular}

Uji Kesesuaian Model Persamaan Struktural

Selanjutnya, model persamaan struktural ini diolah dengan menggunakan software AMOS 22.0 model second order. Gambar 2 adalah hasil model akhir yang telah memenuhi kriteria model fit. Evaluasi kesesuaian model dapat dilihat pada Tabel 3. 


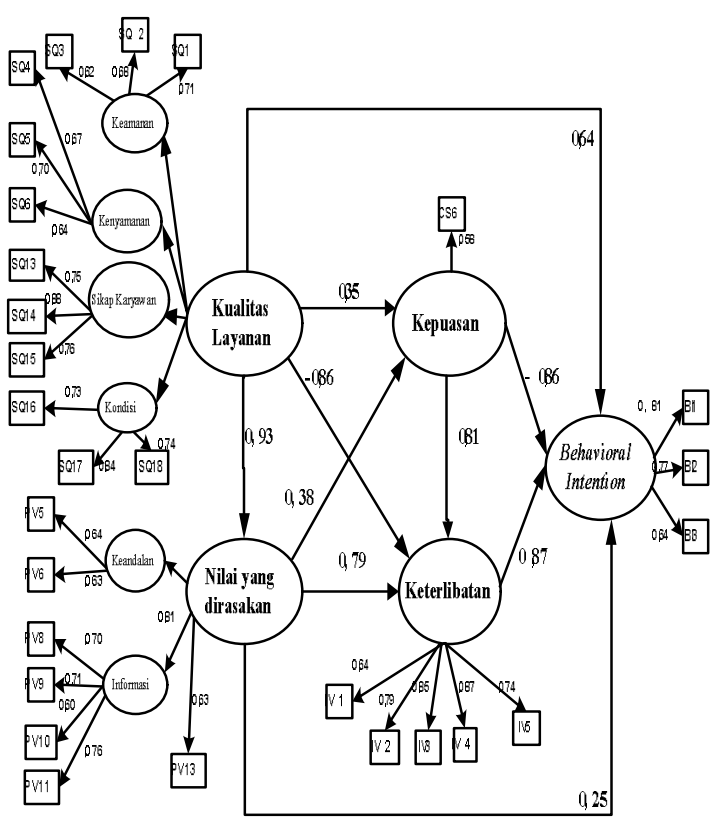

Gambar 2. Model akhir penelitian

Tabel 2. Evaluasi kesesuaian model

\begin{tabular}{lccc}
\hline \multicolumn{1}{c}{ Kriteria } & Hasil & Nilai Kritis & Evaluasi \\
\hline Probabilitas & 0,048 & $\geq 0,05$ & Marjinal \\
CMIN/DF & 1,943 & $\leq 2,00$ & Baik \\
TLI & 0,947 & $\geq 0,95$ & Marjinal \\
CFI & 0,961 & $\geq 0,95$ & Baik \\
RMSEA & 0,072 & $\leq 0,08$ & Baik \\
\hline
\end{tabular}

\section{Uji Reliabilitas}

Reliabilitas adalah sebuah tolak ukur menguji konsistensi indikator dalam mengindikasikan sebuah konstruk. Reliabilitas dalam model persamaan struktural ini dapat dilihat dari nilai construct reliability dan variance extract.

Tabel 3. Construct reliability dan variance extract

\begin{tabular}{|c|c|c|c|c|}
\hline & Loading & Error & $\begin{array}{l}\text { Construct } \\
\text { reliability }\end{array}$ & $\begin{array}{c}\text { Variance } \\
\text { extract }\end{array}$ \\
\hline \multicolumn{3}{|c|}{ Kualitas Layanan } & 0,9305 & 0,5297 \\
\hline SQ1 & 0,71 & 0,552 & & \\
\hline SQ2 & 0,68 & 0,592 & & \\
\hline SQ3 & 0,62 & 0,602 & & \\
\hline SQ4 & 0,67 & 0,523 & & \\
\hline SQ5 & 0,70 & 0,504 & & \\
\hline SQ6 & 0,64 & 0,563 & & \\
\hline SQ13 & 0,75 & 0,446 & & \\
\hline SQ14 & 0,88 & 0,220 & & \\
\hline SQ15 & 0,76 & 0,390 & & \\
\hline SQ16 & 0,73 & 0,397 & & \\
\hline SQ17 & 0,84 & 0,299 & & \\
\hline SQ18 & 0,74 & 0,371 & & \\
\hline$\Sigma$ & 8,69 & 5,46 & & \\
\hline Nilai ya & g dirasakan & & 0,8485 & 0,5123 \\
\hline
\end{tabular}

Jurnal Teknik Industri, Vol. X, No. 2, Mei 2015

\begin{tabular}{lrrrr}
\hline PV5 & 0,64 & 0,625 & & \\
PV6 & 0,63 & 0,704 & & \\
PV8 & 0,70 & 0,48 & & \\
PV9 & 0,71 & 0,426 & & \\
PV10 & 0,60 & 0,641 & & \\
PV11 & 0,76 & 0,396 & & \\
PV13 & 0,63 & 0,563 & & \\
$\Sigma$ & 4,66 & 3,84 & & \\
\hline Kepuasan & & & 0,3376 & 0,3376 \\
\hline CS6 & 0,58 & 0,554 & & \\
\hline Keterlibatan & & & 0,8864 & 0,6124 \\
\hline IV1 & 0,64 & 0,643 & & \\
IV2 & 0,79 & 0,419 & & \\
IV3 & 0,85 & 0,377 & & \\
IV4 & 0,87 & 0,318 & & \\
IV5 & 0,74 & 0,479 & & \\
$\Sigma$ & 3,89 & 2,24 & & \\
\hline Behavioral intention & & 0,7835 & 0,5491 \\
\hline BI1 & 0,81 & 0,307 & & \\
BI2 & 0,77 & 0,43 & & \\
BI3 & 0,64 & 0,836 & & \\
$\Sigma$ & 2,21 & 1,57 & & \\
\hline \multicolumn{5}{c}{} \\
\hline
\end{tabular}

Suatu variabel dikatakan memiliki reliabilitas yang baik bila nilai construct reliability-nya $>0,70$ 0,80 dan nilai variance extract-nya $>0,50$ (Ghozali, 2006). Tabel 3 menunjukkan bahwa semua variabel telah memiliki reliabilitas yang baik kecuali variabel kepuasan karena hanya memiliki satu indikator.

\section{Pengujian Hipotesis Penelitian}

Pengujian hipotesis ini dilakukan dengan melihat ini $C R$ masing-masing variabel atau nilai probabilitas $(p)$ hasil dari pengolahan data dan membandingkannya dengan nilai batasan statistik yang disyaratkan. Nilai $C R$ yang disyaratkan adalah di atas 1,96 atau nilai probabilitasnya di bawah 0,05 (Ghozali, 2006; Hair dkk., 2010). Dengan memenuhi persyaratan tersebut, hipotesis yang diajukan dalam penelitian ini dapat diterima. Hasil regression weight dan critical ratio dari model persamaan struktural selengkapnya dapat dilihat pada Tabel 4.

Tabel 4. Regression weight dan critical ratio

\begin{tabular}{llcccl}
\hline & & Estimate & $\boldsymbol{C R}$ & $\boldsymbol{p}$ & \multicolumn{1}{c}{ Hipotesis } \\
\hline H1 & PV $\leftarrow$ SQ & 0,931 & 2,04 & 0.01 & Tak ditolak \\
H2 & CS $\leftarrow$ SQ & 0,352 & 0,793 & 0,154 & Ditolak \\
H5 & CS $\leftarrow$ PV & 0,385 & 0,753 & 0,089 & Ditolak \\
H3 & IV $\leftarrow$ SQ & $-0,862$ & 0,787 & 0,123 & Ditolak \\
H6 & IV $\leftarrow$ PV & 0,795 & 3,897 & 0.01 & Tak ditolak \\
H8 & IV $\leftarrow$ CS & 0,813 & 3,158 & 0.01 & Tak ditolak \\
H7 & BI $\leftarrow$ PV & 0,254 & 1,01 & 0,089 & Ditolak \\
H10 & BI $\leftarrow$ IV & 0,876 & 4,547 & 0.01 & Tak ditolak \\
H9 & BI $\leftarrow$ CS & $-0,864$ & 1,21 & 0,254 & Ditolak \\
H4 & BI $\leftarrow$ SQ & 0,647 & 2,145 & 0.01 & Tak ditolak \\
\hline \multicolumn{5}{l}{ SQ: kualitas layanan; PV: nilai yang dirasakan; CS: kepuasan } \\
penumpang; IV: keterlibatan; BI: behavioral intention
\end{tabular}

Berdasarkan hasil di atas, didapatkan hasil rekapitulasi pengujian hipotesis-hipotesis yang tak dapat ditolak, yaitu sebagai berikut: 
1. H1 : Kualitas layanan mempunyai efek yang positif terhadap nilai yang dirasakan. Hasil ini mendukung hasil penelitian oleh Cronin dkk. (2000) dan Zeithaml (1988).

2. H4 : Kualitas layanan mempunyai efek yang positif terhadap behavioral intention. Hasil penelitian ini sesuai dengan konsep yang disampaikan oleh penelitian Cronin dkk. (2000) dan Chen (2008).

3. H6 : Nilai yang dirasakan mempunyai efek yang positif terhadap keterlibatan. Hasil ini mendukung penelitian dari Sumaedi dkk. (2012) dan teori perilaku dari Blackwell dkk. (2001), Mowen (1993), dan Solomon (2011).

4. H8 : Kepuasan mempunyai efek yang positif terhadap keterlibatan. Hasil penelitian menunjukkan bahwa adanya pengaruh positif variabel kepuasan terhadap keterlibatan. Hal ini mendukung hasil penelitian dari efek moderasi keterlibatan pada hubungan kepuasan dan loyalitas menurut Beatty dkk. (1988) dan Zaichkowsky (1994).

5. H10 : Keterlibatan mempunyai efek yang positif terhadap behavioral intention. Adapun hubungan antara keterlibatan dengan behavioral intention pada penelitian ini terdapat pengaruh signifikan positif. Hal ini dijelaskan pula pada hasil penelitian Sumaedi dkk. (2012).

\section{Kesimpulan}

Setelah dilakukan penelitian pada KRL Jabodetabek serta dilakukan pengolahan data, maka dapat disimpulkan bahwa kualitas layanan memiliki dampak positif terhadap nilai yang dirasakan. Nilai yang dirasakan dan kepuasan penumpang mempunyai dampak positif terhadap keterlibatan. Kualitas layanan dan keterlibatan memiliki dampak positif terhadap behavioral intention. Namun kualitas layanan dan nilai yang dirasakan tidak berdampak positif terhadap kepuasan. Kualitas layanan juga tidak berpengaruh terhadap keterlibatan. Nilai yang dirasakan dan kepuasan penumpang KRL tidak berpengaruh signifikan terhadap behavioral intention

Dari pengolahan data, indikator yang paling mempengaruhi pada variabel kualitas layanan adalah keamanan perjalanan dan keamanan terhadap kriminalitas. Indikator yang paling mempengaruhi variabel nilai yang dirasakan adalah informasi benar dan mudah dipahami. Pada variabel keterlibatan, indikator yang berpengaruh adalah keterlibatan penumpang dalam memperoleh informasi dan niat menggunakan kereta sebagai pilihan moda transportasi. Sedangkan untuk variabel behavioral intention adalah tingkat kepercayaan dan rekomendasi penumpang.

\section{Implikasi Manajerial dan Agenda Penelitian Mendatang}

Berdasarkan hasil penelitian, prioritas KRL Commuter Line agar menjadi moda transportasi yang memiliki penilaian yang baik dari masyarakat adalah dengan meningkatkan pelayanan dari segala segi dari peraturan, kemampuan pegawai dalam memberikan pelayanan kepada penumpang, fasilitas harus diremajakan dan melakukan modernisasi hal ini perawatan secara rutin sangat dibutuhkan, tingkat keamanan dalam kereta dan media informasi dan promosi harus digencarkan.

Agenda untuk penelitian selanjutnya adalah mengembangkan lebih jauh model ini dengan menambahkan variabel lain yang berkaitan dengan behavioral intention. Namun penelitian ini dapat sebagai referensi model penelitian awal untuk meningkatkan behavioral intention pada transportasi umum. Pada penelitian selanjutnya dapat dilibatkan sampel responden untuk jenis transportasi umum lain.

\section{Daftar Pustaka}

Beatty, S.E., Kahle, L.R. , \& Homer, P. (1988). The involvement - commitment model: Theory and implications. Journal of Business Resources, $16,149-167$.

Bennett, R., Hartel, C.E.J., \& Ma Coll-Kennedy, J.R. (2005). Experience as a moderator of involvement and satisfaction on brand loyalty in a business-to-business setting. Journal of Business Resources, 34, 97-107.

Blackwell, R.D., Miniard, P.W., Engel, J.F. (2001). Consumer Behaviour. 9th Ed. Forth Worth: Harcourt College Publishers.

Chen, C.F. (2008). Investigating structural relationships between service quality, perceived value, satisfaction, and behavioral intentions for air passengers: Evidence from Taiwan. Transport Resources Part A, 42(4), 709-717.

Chen, C.F., \& Tsai, M.H. (2008). Perceived value, satisfaction, and loyalty of TV travel product shopping: Involvement as a moderator. Tourism Management, 29, 1166-1171.

Cronin, J.J., Brady, M.K., \& Hult, G.T.M. (2000). Assessing the effects of quality, value and customer satisfaction on consumer behavioral intentions in service environments. Journal of Retailing, 76(2), 193-218.

Cronin, J.J., \& Taylor, S.A. (1992). Measuring service quality: are examination and extension. Journal of Marketing, 56, 55-68.

Ghozali, I. (2006). Structural Equation Modeling, Semarang: Penerbit Universitas Diponegoro.

Hair, J.F., Anderson, R.E., Tatham, R. L., Black, W.C. (2010). Multivariate Data Analysis. 6th Ed. New Jersey: Prentice Hall.

Hu, K.C., \& Jen, W. (2006). Passengers' perceived service quality of city buses in Taipei: Scale development and measurement. Transportation Rev., 26(5), 645-662.

Irawan , H. (2008). Sepuluh Prinsip Kepuasan Pelanggan. Jakarta: Penerbit Elex Media Komputindo. 
Jen, W., \& Hu, K.C. (2003). Application of perceived value model to identify factors affecting passengers' repurchase intentions on city bus: A case of the Taipei metropolitan area. Transportation, 30, 307-327.

Joewono, T.B., \& Kubota,H. (2007). User satisfaction with paratransit in competition with motorization in Indonesia: Anticipation of future implications. Transportation, 34, 337354.

Lai, W.T., \& Lu, J.L. (2007). Modeling the working mode choice, ownership and usage of car and motorcycle in Taiwan. Journal of the Eastern Asia Society for Transportation Studies, 7, 869-895.

Lam, S.Y., Shankar, V., Erramilli, M. K., \& Murthy, B. (2004). Customer value, satisfaction, loyalty, and switching costs: An illustration from a business-to- business service context. Journal of Academy Market Science, 32(3), 293-311.

Mowen, J.C. (1993). Consumer Behavior. 3rd Ed. New York: Macmillan Publishing Company.

Parasuraman, A., Zeithaml, V.A., \& Berry, L. (1985). A conceptual model of service quality and its implications for future research. Journal of Marketing, 49(4), 41-50.

Parasuraman, A., Zeithaml, V.A., \& Berry, L. (1988). A multiple item scale for measuring consumer perceptions of service quality. Journal of Retailing, 64(1), 12-40.
Peter, J.P., \& Olson, J.C. (2008). Consumer Behavior and Marketing Strategy. 8th Ed. Boston: McGraw-Hill Education.

Schiffman, L.G., Kanuk, L.L., \& Wisenblit, J. (2010). Consumer Behavior. 10th Ed. New Jersey: Pearson Education.

Solomon, M.R. (2011). Consumer Behavior: Buying, Having, and Being. 9th Ed. New Jersey: Pearson Education, Inc.

Sumaedi, dkk. (2012). The empirical study of public transport passengers' behavioral intentions: the roles of service quality, perceived sacrifice, perceived value, and satisfaction (Case study: Paratransit Passengers in Jakarta, Indonesia). International Journal for Traffic and Transport Engineering, 2(1): 83-97.

Roehm et al. (2002). Designing Loyalty-Building Programs for packaged goods Brands. Journal of Marketing Research, 39(2), 202-213.

Zaichkowsky, J.L. (1994). The personal involvement inventory: Reduction, reversion, and application to advertising. Journal of Advertising, 23(4), 59-70.

Zeithaml, V.A. (1988). Consumer perceptions of price, quality and value: A means- end model and synthesis of evidence. Journal of Marketing, 52(July), 2-22.

Zeithaml, V.A., Berry, L.L., \& Parasuraman, A. (1996). The behavioral consequences of service quality. Journal of Marketing, 60(2), 31-46. 